\title{
The diagnostic dilemma of gallbladder volvulus: Report of
}

\section{a case}

\author{
Anuradha R. Bhama ${ }^{1}$, Abdi Ahari ${ }^{2}$ and Hui Sen Chong ${ }^{1 *}$ \\ ${ }^{1}$ Department of Surgery, University of Iowa, Iowa City, Iowa, USA \\ ${ }^{2}$ Mercy Medical Center, North Iowa, St. Mason City, Iowa, USA
}

\begin{abstract}
Gallbladder volvulus is a rare condition that typically affects elderly patients who present with a presumed diagnosis of acute cholecystitis. Often preoperative imaging is unable to definitively diagnosis volvulus. A 90 year old female presented with a four day history of abdominal pain and was found to have peritoneal signs on examination. CT scan was obtained concerning for necrosis of the gallbladder. She was taken for emergent laparoscopic cholecystectomy, which was converted to an open procedure upon the realization of volvulus. The patient's postoperative recovery was uneventful and she was discharged to a nursing facility on postoperative day four. Gallbladder volvulus should be considered in the differential diagnosis of the elderly patient with presumed acute cholecystitis.
\end{abstract}

\section{Introduction}

Gallbladder volvulus is a known but rare condition that often presents with acute abdomen in the elderly population. Less than 500 cases have been previously reported and the incidence is unknown. Only a few have reported a preoperative diagnosis of gallbladder volvulus, and imaging remains non-diagnostic. Patients are presumed to have acute cholecystitis in the setting of normal liver function testing. Gallbladder volvulus requires immediate operative intervention to avoid potential complications, while acute cholecystitis usually does not require immediate surgical attention. Though this is a rare condition, it is important to include gallbladder volvulus in the differential diagnosis when evaluating an elderly patient with acute onset of right upper quadrant pain.

\section{Case report}

A 90 year old female with no past surgical history presented with four days of abdominal pain, nausea, vomiting and anorexia. She reported no fevers or change in bowel habits. Physical examination revealed an afebrile hemodynamically stable patient. Her abdomen was soft, mildly distended but was extremely tender to palpation at the right upper quadrant region. The tenderness was associated with involuntary guarding. No mass was appreciated. The remainder of her physical exam was within normal limits. Laboratory evaluation revealed a white blood cell count of 14,800 and normal liver function test. CT scan of the abdomen and pelvis revealed a distended and likely necrotic gallbladder without cholelithiasis (Figure 1). This was associated with fat stranding and a significant amount of pericholecystic fluid. The patient was taken to the operating room for laparoscopic cholecystectomy. Upon diagnostic laparoscopy, the patient's gallbladder was found to be distended, necrotic and volvulized on its mesentery, along the axis of the cystic duct and cystic artery (Figure 2 and 3). As the anatomy was unclear, the case was converted to an open procedure via a right subcostal incision. The gallbladder was detorsed and the cystic duct and artery were then clearly identified and ligated. The gallbladder was noted to be nonadherent to the liver and was easily resected. The patient's postoperative course was uneventful and she was discharged to a skilled nursing facility on postoperative day four. Final pathology revealed acute cholecystitis with extensive hemorrhage, focal acute inflammation and loss of surface mucosa. No cholelithiasis was identified.

\section{Discussion}

Acute torsion of the gallbladder is a rare entity in the United States. Initially reported by Wendel in 1898 [1], this phenomenon has been described by several authors internationally and seems to have become more common in the past decade.

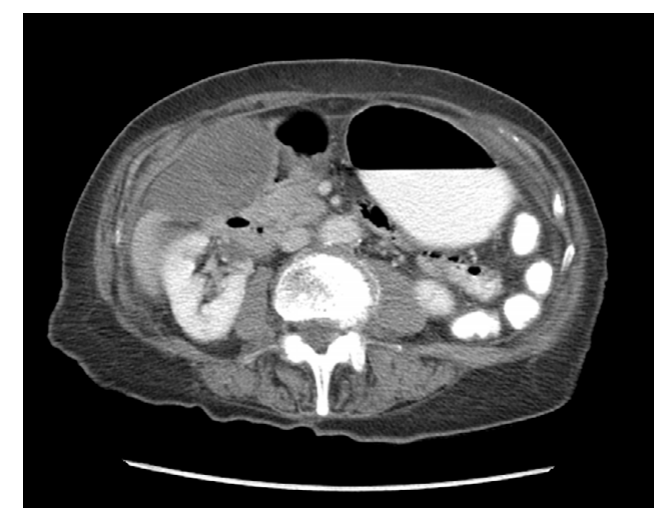

Figure 1. CT scan demonstrating enlarged gallbladder (labelled GB) without stones.

Correspondence to: Hui Sen Chong, M.D., Department of Surgery, University of Iowa, 200 Hawkins Drive, Iowa City, Iowa 52241, Tel: 319-356-1616, Fax: 319356-8682; E-mail: huisen-chong@uiowa.edu

Key words: gall bladder volvulus, elderly, acute abdomen

Received: March 01, 2016; Accepted: March 23, 2016; Published: March 28, 2016 


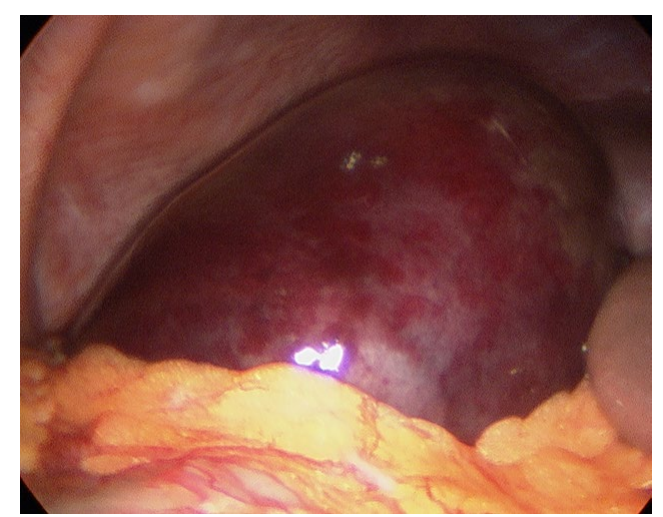

Figure 2. Intraoperative photo of distended and necrotic gall bladder.

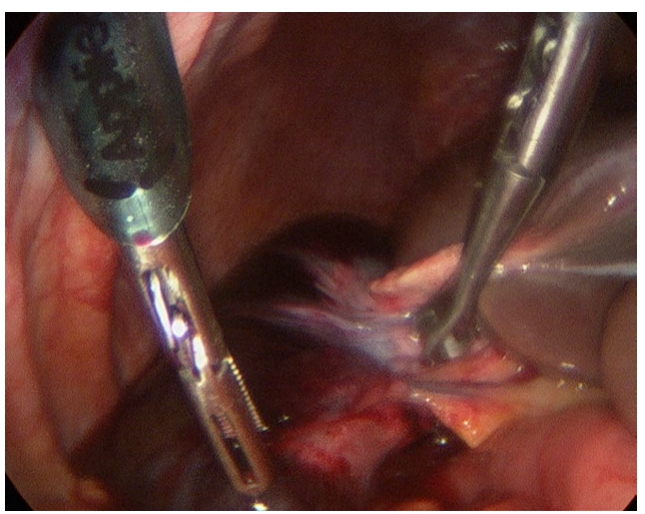

Figure 3. Intraoperative photo of twisted cystic duct pedicle.

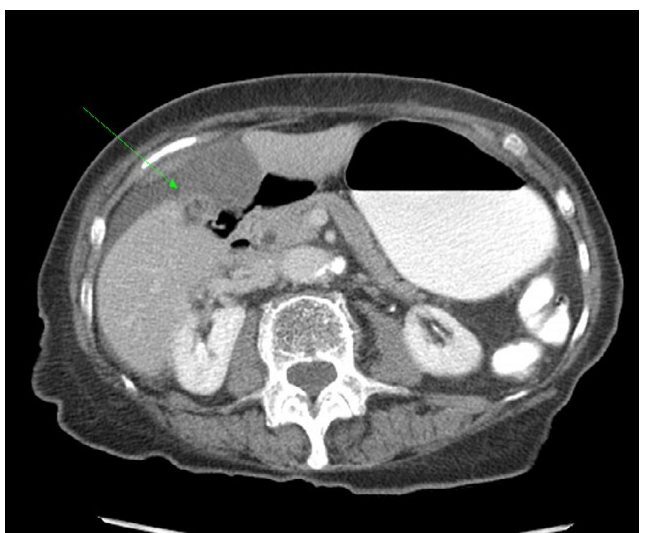

Figure 4. Twisted cystic duct pedicle on CT scan.

This condition often occurs in elderly, thin females, who present with acute abdomen and signs suggestive of acute cholecystitis, specifically right upper quadrant pain without jaundice. A spectrum of abdominal exam findings has been described. Findings have included mild right upper quadrant pain, palpation of a mass, frank peritonitis $[2,3]$, or suspected acute appendicitis $[4,5]$. On laboratory evaluation, these patients do not exhibit signs of biliary obstruction or elevation of liver function tests. However, leukocytosis may be present, indicating an inflammatory response. Our patient presented with this clinical picture, including peritoneal signs on exam and no signs of biliary obstruction on laboratory evaluation.

Table 1 summarizes all of the reported cases in the English literature since the advent of laparoscopic cholecystectomy by Enrich Muhe [6]. As described above, most of these patients are elderly female patients who presented with RUQ pain without a palpable abdominal mass. In most cases, the initial diagnosis was acute or acalculous cholecystitis. However, seven out of 45 cases were diagnosed as gallbladder volvulus preoperatively. Interestingly, a majority of these cases were diagnosed on CT scan, which is not the traditional imaging modality for gallbladder pathology. In hind-sight, our patient's torsion was visible on CT scan. Unlike our patient, most of the patients who presented with gallbladder volvulus did not have peritonitis or an acute abdomen. They therefore underwent further workup with hepatobiliary iminodiacetic acid (HIDA) scan, magnetic resonance imaging (MRI), or magnetic resonance cholangiopancreatography (MRCP), which revealed findings of a volvulized gallbladder.

From a clinical standpoint, gallbladder volvulus can show up on imaging as a distended, hydropic gallbladder with thickened wall and pericholecystic fluid. It has been previously suggested that ultrasound may be the instrumental for the diagnosis, with a triad of radiologic findings including: anterior localization of the gallbladder; increased volume of the gallbladder; and a severely thickened, multilayered gallbladder wall [14]. Our patient's physical exam prompted evaluation in the emergency department with a CT scan. Chen et al. suggested that gallbladder volvulus can be identified on the CT scan using the " $U$ to 9 to O" sign [34]; however, this sign was not evident on our patient's imaging. Upon retrospective review of our patient's CT scan, one can appreciate a twist of the gallbladder along the axis of the cystic duct (Figure 4). The use of MRCP to diagnose gallbladder volvulus has been reported $[20,26]$. However, the majority of these patients present with an acute abdomen, requiring prompt surgical intervention, thus negating any additional studies; a result, only $1 \%$ of reported cases of gallbladder volvulus were diagnosed preoperatively [41].

\section{Conclusion}

The exact cause of gall bladder volvulus remains unknown. Suggested mechanisms for torsion include: congenital deformities, a long peritoneal mesentery, generalized visceroptosis, forceful peristalsis of nearby organs, cholelithiasis, or atherosclerosis of the cystic artery $[10,18]$. The acute torsion initially results in venous congestion of the gall bladder, leading to engorgement of the organ, followed by acute internal hemorrhage as the mucosa becomes necrotic. This clinical entity has been described sporadically in the literature and remains a rare or under-reported phenomenon. While this diagnosis has been made radiographically, the use of imaging is difficult in cases where patients present with peritonitis requiring emergent operation.

The gallbladder in a gallbladder volvulus case can be resected laparoscopically; however, the triangle of Calot may be difficult to be identified due to torsion of the gallbladder along the cystic duct axis. Therefore, laparotomy may be necessary in order to safely evaluate the anatomy prior to its resection. To summarize, although rare, it is important to consider gallbladder volvulus as a differential diagnosis in the elderly patient with right upper quadrant pain and peritonitis, especially if the clinical situation does not permit time for additional radiographic studies.

\section{Conflict of interest}

Anuradha R. Bhama, MD and other co-authors have no conflict of interest. 
Table 1. Gall bladder volvulus case reports since advent of laparoscopic cholecystectomy in 1986.

\begin{tabular}{|c|c|c|c|c|c|c|c|c|c|c|c|}
\hline & Author, year & $\mathbf{N}$ & Age & Sex & Signs \& Symptoms & Peritonitis & $\begin{array}{c}\text { Attempted } \\
\text { Methods of } \\
\text { Diagnosis }\end{array}$ & $\begin{array}{l}\text { Suspected preop } \\
\text { diagnosis }\end{array}$ & $\begin{array}{l}\text { Method of } \\
\text { Diagnosis }\end{array}$ & $\begin{array}{c}\text { Lap } \\
\text { v } \\
\text { Open }\end{array}$ & Outcome \\
\hline \multirow[t]{2}{*}{1} & McHenrey [7] & 2 & 87 & $\mathrm{~F}$ & epigastric pain & no & AXR, US & $\mathrm{AC}$ & exploration & open & uncomplicated \\
\hline & & & 80 & $\mathrm{~F}$ & generalized abdominal pain & no & AXR & $\begin{array}{c}\text { partial large bowel } \\
\text { obstruction }\end{array}$ & exploration & open & uncomplicated \\
\hline 2 & Van der Veken [8] & 1 & 83 & $\mathrm{~F}$ & RLQ pain & no & AXR & acute appendicitis & exploration & open & uncomplicated \\
\hline \multirow[t]{2}{*}{3} & Alden [9] & 2 & 78 & $\mathrm{~F}$ & RUQ pain & no & US & $\mathrm{AC}$ & exploration & open & uncomplicated \\
\hline & & 1 & 91 & $\mathrm{~F}$ & chest and abdominal pain & no & US & $\mathrm{AC}$ & exploration & open & uncomplicated \\
\hline 4 & Macdonald [10] & 1 & 74 & M & $\begin{array}{l}\text { RUQ pain and abdominal } \\
\text { mass }\end{array}$ & no & none & $\mathrm{AC}$ & exploration & open & uncomplicated \\
\hline 5 & $\begin{array}{c}\text { Gonzalez-Fisher } \\
{[11]}\end{array}$ & 1 & 56 & $\mathrm{~F}$ & RUQ pain & no & US & $\mathrm{AC}$ & exploration & open & uncomplicated \\
\hline 6 & Nguyen [12] & 1 & 91 & $\mathrm{~F}$ & crampy abdominal pain & no & AXR, US, CT, & $\mathrm{AC}$ & exploration & laparoscopy & uncomplicated \\
\hline 7 & Schroder [13] & 1 & 18 & $\mathrm{~F}$ & & & & & exploration & laparoscopy & \\
\hline 8 & Hamdi [14] & 1 & 90 & $\mathrm{~F}$ & RUQ pain & no & AXR, US & $\mathrm{AC}$ & exploration & open & uncomplicated \\
\hline 9 & McAleese [15] & 1 & 85 & $\mathrm{~F}$ & RUQ pain & no & US & $\mathrm{AC}$ & exploration & laparoscopy & $\begin{array}{l}\text { postoperative bleeding } \\
\text { diverticuli requiring } \\
\text { redadmission }\end{array}$ \\
\hline 10 & Christoudias [16] & 1 & 82 & $\mathrm{~F}$ & left chest pain & no & US & $\mathrm{AC}$ & exploration & laparoscopy & uncomplicated \\
\hline 11 & Losken [17] & 1 & 80 & $\mathrm{~F}$ & epigastric pain & no & AXR & bowel obstruction & $\mathrm{AC}$ & open & uncomplicated \\
\hline 12 & Ikematsu [18] & 6 & $\begin{array}{l}77- \\
91\end{array}$ & $\mathrm{~F}$ & & & & & & & \\
\hline 13 & Khosraviani [19] & 1 & 86 & $\mathrm{~F}$ & $\begin{array}{l}\text { RUQ pain and abdominal } \\
\text { mass }\end{array}$ & no & US & $\mathrm{AC}$ & exploration & $\begin{array}{c}\text { not } \\
\text { commented }\end{array}$ & uncomplicated \\
\hline 14 & Usui [20] & 1 & 78 & $\mathrm{~F}$ & epigastric pain & no & $\begin{array}{l}\text { CT, US, MRI, } \\
\text { MRCP, }\end{array}$ & GBV & MRCP & open & uncomplicated \\
\hline 15 & Rajagopal [21] & 1 & 70 & $\mathrm{~F}$ & $\begin{array}{l}\text { RUQ pain and abdominal } \\
\text { mass }\end{array}$ & no & US, CT & $\mathrm{AC}$ & exploration & open & uncomplicated \\
\hline 16 & Kim [22] & 1 & 73 & $\mathrm{~F}$ & $\mathrm{n} / \mathrm{a}$ & $\mathrm{n} / \mathrm{a}$ & $\mathrm{n} / \mathrm{a}$ & $\mathrm{n} / \mathrm{a}$ & $\mathrm{n} / \mathrm{a}$ & $\mathrm{n} / \mathrm{a}$ & $\mathrm{n} / \mathrm{a}$ \\
\hline 17 & $\begin{array}{c}\text { Ortiz-Gonzalez } \\
{[23]}\end{array}$ & 1 & 90 & $\mathrm{~F}$ & RUQ pain & yes & AXR & acute appendicitis & exploration & open & uncomplicated \\
\hline 18 & Cho [24] & 1 & 94 & $\mathrm{~F}$ & $\begin{array}{l}\text { RLQ pain and abdominal } \\
\text { mass }\end{array}$ & no & $\mathrm{CT}$ & GBV & $\mathrm{CT}$ & laparoscopy & uncomplicated \\
\hline \multirow[t]{2}{*}{19} & Shaikh [25] & 2 & 79 & M & RUQ pain & no & US, CT & hydrops of GB & exploration & open & uncomplicated \\
\hline & & & 84 & M & RUQ pain & no & US & $\mathrm{AC}$ & exploration & laparoscopy & uncomplicated \\
\hline 20 & Matsuhashi [26] & 1 & 54 & $\mathrm{~F}$ & RUQ pain & no & $\begin{array}{l}\text { US, CT, MRI, } \\
\text { MRCP }\end{array}$ & $\begin{array}{l}\text { necrotic gall } \\
\text { bladder }\end{array}$ & exploration & open & uncomplicated \\
\hline 21 & Tarhan [27] & 1 & 70 & M & RUQ pain & no & AXR, US & $\mathrm{AC}$ & exploration & open & wound infection \\
\hline 22 & Faure [28] & 1 & 84 & $\mathrm{~F}$ & $\begin{array}{l}\text { RUQ pain and abdominal } \\
\text { mass }\end{array}$ & no & US, CT & GBV & $\mathrm{CT}$ & laparosocpy & uncomplicated \\
\hline 23 & Kimura [29] & 1 & 11 & M & RUQ pain & no & US, CT, MRI & GBV & MRI & laparoscopy & uncomplicated \\
\hline \multirow[t]{2}{*}{24} & Malherbe [30] & 2 & 86 & $\mathrm{~F}$ & RUQ pain & no & US, CT, EUS & $\mathrm{AC}$ & exploration & open & uncomplicated \\
\hline & & & 80 & $\mathrm{~F}$ & $\begin{array}{l}\text { diffuse abdominal pain } \mathrm{w} \\
\text { palpable mass }\end{array}$ & no & $\mathrm{CT}$ & $\mathrm{AC}$ & exploration & laparoscopy & $\begin{array}{c}\text { postoperative pleural } \\
\text { effusions }\end{array}$ \\
\hline 25 & Caliskan [31] & 1 & 79 & $\mathrm{~F}$ & $\begin{array}{l}\text { RUQ pain and abdominal } \\
\text { mass }\end{array}$ & no & US & $\begin{array}{l}\text { acalculous } \\
\text { cholecystitis }\end{array}$ & exploration & open & uncomplicated \\
\hline 26 & Lavy [32] & 1 & 85 & $\mathrm{~F}$ & RUQ pain & yes & $\mathrm{CT}$ & GBV & $\mathrm{CT}$ & $\begin{array}{c}\text { not } \\
\text { commented }\end{array}$ & uncomplicated \\
\hline 27 & Bagnato [33] & 1 & 85 & M & RUQ pain & yes & AXR, US & $\begin{array}{l}\text { acalculous } \\
\text { cholecystitic }\end{array}$ & exploration & open & uncomplicated \\
\hline 28 & Chen [34] & 1 & 84 & $\mathrm{~F}$ & RUQ pain & no & AXR, CT, & $\mathrm{AC}$ & exploration & open & uncomplicated \\
\hline 29 & Chittal [35] & 1 & 71 & $\mathrm{~F}$ & cecal volvulus & & & & exploration & & \\
\hline 30 & Inoue [36] & 1 & 95 & M & abdominal pain & no & $\begin{array}{l}\text { CT, US, MRI, } \\
\text { MRCP, }\end{array}$ & GBV & $\mathrm{CT}, \mathrm{MR}$ & laparoscopy & uncomplicated \\
\hline 31 & Mouawad [37] & 1 & 99 & $\mathrm{~F}$ & RUQ pain & no & CT, HIDA, ERCP & $\mathrm{AC}$ & exploration & open & uncomplicated \\
\hline 32 & Alevizos [38] & 1 & 95 & $\mathrm{~F}$ & $\begin{array}{l}\text { RUQ pain and abdominal } \\
\text { mass }\end{array}$ & no & $\mathrm{CT}$ & $\mathrm{n} / \mathrm{a}$ & exploration & laparoscopy & uncomplicated \\
\hline 33 & Arslan [39] & 1 & 47 & M & RUQ pain & yes & US & $\mathrm{AC}$ & exploration & open & uncomplicated \\
\hline 34 & Miyakura [40] & 1 & 61 & $\mathrm{~F}$ & RUQ pain & no & US, CT & GBV & $\mathrm{CT}$ & laparoscopy & uncomplicated \\
\hline
\end{tabular}

Key: $\mathrm{AC}=$ acute cholecystitis; $\mathrm{AXR}=$ abdominal $\mathrm{x}$-ray; $\mathrm{CT}=$ computed tomography; $\mathrm{ERCP}=$ endoscopic retrograde cholangiopancreatography; $\mathrm{GBV}=$ gall bladder volvulus; $\mathrm{HIDA}=$ hepatobiliary iminodiacetic acid scan; $\mathrm{MRCP}=$ magnetic resonance cholangiopancreatography; $\mathrm{MRI}=$ magnetic resonance imaging; US = ultrasound 


\section{References}

1. Wendel AV (1898) VI. A Case of Floating Gall-Bladder and Kidney complicated by Cholelithiasis, with Perforation of the Gall-Bladder. Ann Surg 27: 199-202. [Crossref]

2. Ortiz-Gonzälez J, Reyes-Segura MP, Gutierrez-Carrillo F, Vega-Chavaje RG (2003) Volvulus of the gallbladder. Dig Dis Sci 48: 1116-1117. [Crossref]

3. Bagnato C, Lippolis P, Zocco G, Galatioto C, Seccia M (2011) Uncommon cause of acute abdomen: volvulus of gallbladder with necrosis. Case report and review of literature. Ann Ital Chir 82: 137-140. [Crossref]

4. Alevizos L, Stamou KM, Tsamis D, Pattas M, Menenakos E, et al. (2012) Gallbladder volvulus as a cause of an acute abdomen in a 95-year-old patient. Am Surg 78: E4748. [Crossref]

5. Rueda-Martínez JL C-SP, Vázquez-Aragón P, Valero-Liñán AS, Prat-Calero A (2012) Gallbladder volvulus: clinical presentation mimicking acute appendicitis of the elderly. Rev Esp Enferm Dig 103: 656-657. [Crossref]

6. Mühe E (1991) [Laparoscopic cholecystectomy]. Z Gastroenterol Verh 26: $204-$ 206. [Crossref]

7. McHenry CR, Byrne MP (1986) Gallbladder volvulus in the elderly. An emergent surgical disease. J Am Geriatr Soc 34: 137-139. [Crossref]

8. Van der Veken E, Azagra JS, de Prez C (1986) Gallbladder volvulus: a case report. Acta Chir Belg 86: 267-269. [Crossref]

9. Alden PB, Miller JB, Gamble WG (1989) Volvulus of the gallbladder. Report of two cases and review of the literature. Minn Med 72: 653-656. [Crossref]

10. Macdonald PH, Pace RF (1990) Volvulus of the gallbladder: a case report. Can J Surg 33: 282-283. [Crossref]

11. Gonzalez-Fisher RF, Vargas-Ramirez L, Rescala-Baca E, Dergal-Badue E (1993) Gallbladder volvulus. HPB Surg 7: 147-148. [Crossref]

12. Nguyen T, Geraci A, Bauer JJ (1995) Laparoscopic cholecystectomy for gallbladder volvulus. Surg Endosc 9: 519-521. [Crossref]

13. Schroder DM, Cusumano DA 3rd (1995) Laparoscopic cholecystectomy for gallbladder torsion. Surg Laparosc Endosc 5: 330-334. [Crossref]

14. Hamdi M, Blondiau JV, Algaba R, Van Gysel JP (1996) Gallbladder volvulus: a case report. Could the ultrasound be the key of the early diagnosis? Acta Chir Belg 96: 4143. [Crossref]

15. McAleese P, Kolachalam R, Zoghlin G (1996) Saint's triade presenting as volvulus of the gallbladder. J Laparoendosc Surg 6: 421-425. [Crossref]

16. Christoudias GC (1997) Gallbladder volvulus with gangrene. Case report and review of the literature. JSLS 1: 167-170. [Crossref]

17. Losken A, Wilson BW, Sherman R (1997) Torsion of the gallbladder: a case report and review of the literature. Am Surg 63: 975-978. [Crossref]

18. Ikematsu Y, Yamanouchi K, Nishiwaki Y, Kida H, Waki S, et al. (2000) Gallbladder volvulus: experience of six consecutive cases at an institute. J Hepatobiliary Pancreat Surg 7: 606-609. [Crossref]

19. Khosraviani K, Thompson NW, Mackle EJ (2000) Volvulus of the gallbladder. Ulster Med J 69: 163-164. [Crossref]

20. Usui M, Matsuda S, Suzuki H, Ogura Y (2000) Preoperative diagnosis of gallbladder torsion by magnetic resonance cholangiopancreatography. Scand J Gastroenterol 35: 218-222. [Crossref]

21. Rajagopal R, Rajagopal A (2001) Acute torsion of the gall bladder. Am J Surg 182: 534-535. [Crossref]
22. Kim SY, Moore JT (2003) Volvulus of the gallbladder: laparoscopic detorsion and removal. Surg Endosc 17: 1849. [Crossref]

23. Ortiz-Gonzälez J, Reyes-Segura MP, Gutierrez-Carrillo F, Vega-Chavaje RG (2003) Volvulus of the gallbladder. Dig Dis Sci 48: 1116-1117. [Crossref]

24. Cho YP, Kim HJ, Jung SM, Kang GH, Han MS, et al. (2005) Torsion of the gallbladder: report of a case. Yonsei Med J 46: 862-865. [Crossref]

25. Shaikh AA, Charles A, Domingo S, Schaub G (2005) Gallbladder volvulus: report of two original cases and review of the literature. Am Surg 71: 87-89. [Crossref]

26. Matsuhashi N, Satake S, Yawata K, Asakawa E, Mizoguchi T, Kanematsu M, et al. (2006) Volvulus of the gall bladder diagnosed by ultrasonography, computed tomography, coronal magnetic resonance imaging and magnetic resonance cholangiopancreatography. World J Gastroenterol 12: 4599-4601. [Crossref]

27. Tarhan OR, Barut I, Dinelek H (2006) Gallbladder volvulus: review of the literature and report of a case. Turk J Gastroenterol 17: 209-211. [Crossref]

28. Faure JP, Doucet C, Scepi M, Rigoard P, Carretier M, et al. (2008) Abnormalities of the gallbladder, clinical effects. Surg Radiol Anat 30: 285-290. [Crossref]

29. Kimura T, Yonekura T, Yamauchi K, Kosumi T, Sasaki T, et al. (2008) Laparoscopic treatment of gallbladder volvulus: a pediatric case report and literature review. $J$ Laparoendosc Adv Surg Tech A 18: 330-334. [Crossref]

30. Malherbe V, Dandrifosse AC, Detrembleur N, Denoel A (2008) Torsion of the gallbladder: two case reports. Acta Chir Belg 108: 130-132. [Crossref]

31. Caliskan K, Parlakgumus A, Koc Z, Nursal TZ (2009) Acute torsion of the gallbladder: a case report. Cases J 2: 6641. [Crossref]

32. Lavy M, Lubrano J, Morati P, Delabrousse E, Idelcadi O, et al. (2010) Gallbladder volvulus diagnosed at computed tomography. Am Surg 76: 1302-1303. [Crossref]

33. Bagnato C, Lippolis P, Zocco G, Galatioto C, Seccia M (2011) Uncommon cause of acute abdomen: volvulus of gallbladder with necrosis. Case report and review of literature. Ann Ital Chir 82: 137-140. [Crossref]

34. Chen Y, Rosati C (2011) Necrotizing volvulus of the gallbladder with a distinct pattern on computed tomography scan. Am Surg 77: E298-300. [Crossref]

35. Chittal R, Harris D, Patel A, Goodyear S, Parkianathan V (2011) An interesting rare case of double volvulus. BMJ Case Rep 2011. [Crossref]

36. Inoue S, Odaka A, Hashimoto D, Tamura M, Osada H (2011) Gallbladder volvulus in a child with mild clinical presentation. Pediatr Radiol 41: 113-116. [Crossref]

37. Mouawad NJ, Crofts B, Streu R, Desrochers R, Kimball BC (2011) Acute gallbladder torsion - a continued pre-operative diagnostic dilemma. World J Emerg Surg 6: 13. [Crossref]

38. Alevizos L, Stamou KM, Tsamis D, Pattas M, Menenakos E, et al. (2012) Gallbladder volvulus as a cause of an acute abdomen in a 95-year-old patient. Am Surg 78: E4748. [Crossref]

39. Arslan ED, Hakbilir O, Uyanik B, Oztürk B, Kaya E, et al. (2012) Gallbladder volvulus. J Pak Med Assoc 62: 965-966. [Crossref]

40. Miyakura Y, Sadatomo A, Ohta M, Lefor AT, Sata N, et al. (2012) Floating gallbladde strangulation caused by the lesser omentum: report of a case. Surg Today 42: 693696. [Crossref]

41. Katz DS, Yam B, Hines JJ, Mazzie JP, Lane MJ, et al. (2008) Uncommon and unusual gastrointestinal causes of the acute abdomen: computed tomographic diagnosis. Semin Ultrasound CT MR 29: 386-398. [Crossref]

Copyright: (C2016 Bhama AR. This is an open-access article distributed under the terms of the Creative Commons Attribution License, which permits unrestricted use, distribution, and reproduction in any medium, provided the original author and source are credited. 